with the Government and of consequent frustration and discouragement possibly due to differences of interpretation of the Overseas Resources Development Act. Lord Reith suggests that a rapid review of the working of that Act might be helpful. He complains particularly of the extent to which applications for projects are held up, apparently through disagreement as to the nature of the work the Corporation should do and the degree of control which the Government should oxercise over it. He points out that the restrictions imposed upon the future activities of the Corporation in the emergent territories will deny them the full use of its unique facilities and managerial experience at the critical transitional stage of their development, in spite of the obligation for ensuring continuing development finance in such territories which the Government appeared to recognize at the Montreal Conference.

\section{Chinese Scientific Literature}

The Lending Library Unit of the Department of Scientific and Industrial Research is now issuing a list of current periodicals received from China. The first list (July 1959) gives the titles of one hundred. periodicals which are being received regularly, and these publications can be borrowed from the Unit by approved borrowers of the Science Museum Library, provided Science Museum Library loan requisition forms are used. Twenty-one of the periodicals listed are obtained by exchange, and special attention is directed to Scientia Sinica (in English) and to Science Record (in English, French, German and Russian). The periodicals listed are annotated according to the category of readers for whom they are intended, and whether they include contents lists or abstracts in a Western European language. This first issue also includes a note on the Chinese phonetic alphabet.

\section{Mordell's "Reflections"}

CAMBRIDGE mathematicians have sometimes mitigated the austerity of their scholarship on retirement, and to this wise relaxation we owe Hardy's "Apology", Littlewood's "Miscellany" and now Mordell's "Reflections" ("Reflections of a Mathematician", by Prof. L. J. Mordell. Pp. vii +50 . Montreal : Canadian Mathematical Congress, Chemistry Building, McGill University or École Polytechnique, 2500 Guyard Avenue. 1959. n.p.). In this collection of short, informal essays, the author is primarily interested in explaining the point of view of the professional mathematician to fellow scholars who are not mathematicians. $\mathrm{He}$ is not concerned with applications, but with mathematics itself-what it is, the fascination of its rsthetics and its techniques, the difficulties and triumphs of creative work, not without some mild insinuation that the theory of numbers is the crown of mathematics. Two of his points deserve emphasis. The first is that the three cardinal virtues for the young mathematician are faith, hope and curiosity, and that the greatest of these is curiosity. Secondly, he stresses that the mathematician's task is not ended when he has solved his problem; he is under an obligation to his fellow-workers to present his results clearly and intelligibly, and must not allow the economic demand for brevity to result in obscurity. The selection of precisely the right number of steps required to support the argument, so that it shall be neither tedious nor obscure, is a matter to which the young mathematician should pay careful attention. Mordell in this connexion quotes with approval Polya's advice: "if you have two things to say, say them one at a time".

\section{Museum of Applied Arts and Sciences, Sydney}

THE Annual Report of the Trustees of the Museum of Applied Arts and Sciences, Sydney, for 1957 (Pp. 20. Sydney: Museum of Applied Arts and Sciences, 1959) stresses the great urgency of allocating a site for a new museum. It points out that a modern science museum requires an extensive area and building, not only to preserve and display its national treasures in an appropriate manner, but also to exhibit full-sized engineering exhibits. Within the limits of the resources of the Museum, provision was made to show the advance of science during the International Geophysical Year. Also by means of films, diagrams and models visitors were presented with the development of guided missiles and space satellites. The results of research by the staff in the field of essential oil are drawing increasing numbers of inquiries from all over the world. Since the Museum deals principally with applied science, it was always necessary to strike a balance between pure and applied research by the staff.

\section{Further Botanical Collections}

THE great tradition of travelling and collecting plants, which, among others, we associate particularly with the name of Linnaeus and his followers and adherents, is still very much alive in Sweden. A recent issue of the Arkiv för Botanik (4, Part 1; 1959 ; Kungl. Svenska Vetenskaps-Akademien, Stockholm) is of special interest in this connexion in that it contains many new floristic records based on expeditions to places of such unique interest as the Juan Fernandez Islands. Several of the contributions, on Hepaticæ (S. Arnell), Mosses (E. B. Bartram), Uredinales (I. Jørstad), relate to materials chiefly collected in the course of an expedition by the eminent Swedish botanist, Dr. C. Skottsberg, and his wife during $1954-55$ to these islands. Some of the records also relate to the Falkland Islands and South America. There is also an account of Annonaceae by von Rob. E. Fries, based on specimens collected by Dr. Eric Asplund during his travels in Ecuador in 1955.

\section{The Ciba Foundation, 1949-59}

THe Ciba Foundation, founded in 1947 by the Swiss firm, Ciba, Ltd., of Basle, for the promotion of international co-operation in medical and chemical research, shows in its report for the years 1949-59 a remarkable record of success. Housed at 41 Portland Place, London, W.1, in a building designed by the brothers Adam which was built in 1778, and is now scheduled as a building of historical and architectural interest, the Foundation, through its Trustees, Executive Council and International Scientific Advisory Panel, has arranged numerous international conforences, colloquia and discussion meetings on various subjects, as well as the Ciba Foundation annual lectures and scientific-film sessions (The Ciba Foundation for the Promotion of International Co-operation in Medical and Chemical Research. Ten Years Report for 1949-1959. Pp. 1-64. The Ciba Foundation, 41 Portland Place, London, W.1). A feature of the colloquia and conferences is that they are attended for three or four days by experts in various fields of work from various countries who are invited to take part, the number attending being kept low, great importance being attached to free discussion and social contacts 